DOI: $10.17805 / g g z .2018 .1 .3$

\title{
Необходимость социально-политической модернизации
}

\author{
Н. Н. Равочкин
}

Кемеровский государственный сельскохозяйственный институт

Статья построена на философском анализе необходимости проведения модернизации сочиальной и политической сфер жизни общества. Проводится обращение к плюрализму подходов к сущчности модернизащии. Раскрывается значимость учета различными обществами культурной идентификащии. Приводятся обоснования необходимости сочииально-политической модернизачии. Обращается внимание на актуальности исследуемой модернизации в российском обществе.

Ключевые слова: модернизаиия; общество; соииальная сфера; политическая сфера; государство; соииальная философия

\section{The Need for Social and Political Modernization \\ N. N. Ravochkin \\ Kemerovo State Agricultural Institute}

The article is based on a philosophical analysis of the need to modernize the social and political spheres of society. The author appeals to the pluralism of approaches to the essence of modernization and reveals the significance of registration of cultural identification by different societies. Reasons for the need for sociopolitical modernization are presented. The attention is drawn to the relevance of modernization in Russian society that is being studied.

Keywords: modernization; society; social sphere; political sphere; state; social philosophy

Социальная философия занимается изучением феноменов и процессов, которые существуют, реализуются и протекают в социальной реальности. Одним из таких указанных процессов является модернизация. В своем стремлении постичь сущность модернизации, социальная философия задается не только вопросом «Что это такое?», но также спрашивает о том, насколько модернизация необходима (для конкретного общества).

Суть проблемы состоит в следующем. С одной стороны, модернизационные механизмы должны реализовываться в определенном контексте, т. е. в так называемой «привязке» к месту и ко времени. С другой стороны эти процессы должны затрагивать определенные сферы (или даже субсферы) обще- 
ства, поскольку в конкретном контексте может складываться необходимость реформирования и улучшения лишь отдельных частей определенной сферы. Третья составляющая проблемы заключается в том, что модернизация как процесс социальных преобразований должен реализовываться вовремя, т. е. являться исторически детерминированным.

В целом социальная философия, занимаясь проблемой модернизации, направлена на рассмотрение всего отмеченного нами множества воплощений этих сторон указанной проблемы. Все это позволяет определить необходимость проведения модернизации, в том числе в социальной и политической сферах общества. Перед тем как предпринять попытку социальнофилософского анализа необходимости таких преобразований, имеет смысл выявить сущность того, чем же является сама модернизация. Е. А. Бритикова в своем стремлении определить сущность модернизационных преобразований утверждает, что сам термин «модернизация» не имеет четко определенного содержания. Однако самое простое и наиболее общепринятое понимание под этим термином понимается «осовременивание» (Бритикова, 2014: 286).

Интеллектуальные основания идей модернизации располагаются в философских концепциях эпохи Просвещения. В рамках этой философской традиции, согласно исследовательской позиции В.С. Рахманина, выделяется следующий ряд парадигмальных установок или специфических черт модернизации:

«- разум гуманистичен;

— нарастание господства человека над природой - основа экономического благополучия и процветания;

— научно-технический прогресс неодолим;

- на основе научно-технического прогресса нарастают не только экономические и социальные ресурсы, но однотипно (более или менее) преобразуется культура всех народов и стран;

- модернизационные процессы имеют общие закономерности, это линейные процессы, хотя разные страны вступают в них в разное время и с разными ресурсами;

- страны “второго и третьего эшелона” модернизации так или иначе должны взять за образец те, что ушли вперед (“модернизация вдогонку”);

- доминантой модернизации во всех обстоятельствах и условиях является технико-экономическое перевооружение экономики;

- модернизационные сдвиги в экономике - путь к демократии и государству всеобщего процветания» (Рахманин, 2011: 42-43).

Совершение операции определения модернизации предполагает освещение нескольких подходов, по-своему интерпретирующих ее сущность. 
Одним из таковых является приоритет эволюции как основания развития общественных структур. Е. А. Бритикова указывает, что в соответствии с общепринятым пониманием модернизации существует ряд подходов к трактовке ее сущности, отражающихся, например, в эволюционном и функциональном развитии всех сторон общества. Это является последствием сначала индустриализации, затем - становления постиндустриального общества. В рамках данного подхода реализуется экономическое развитие общества, что влечет за собой, например, индивидуализацию социальной ткани как результат социальных трансформаций. Кроме того, исследовательница пишет, что «модернизация рассматривалась как системный имманентный процесс, интегрировавший в связное целое факторы и атрибуты модернизации, которые должны были появляться в кластерах, а не в изоляции. Изменения, вносимые в одну из сфер деятельности, неизбежно вызывают адекватные реакции в других сферах» (Бритикова, 2014: 287).

Другой подход образно определяется как реляционный. Его суть заключена в существовании цуеленаправленных попыток, осуществляемых «либо большинством населения, либо элитой для того, чтобы превзойти современные стандарты. Но эти стандарты могут варьировать. “Эпицентры” модернизации не закреплены в каких-то обществах раз и навсегда, напротив, они меняются» (Штомпка, 1996: 174). В данном случае речь идет о том, что в мировом сообществе наличествует определенное количество стран так называемого «первого мира», задающих вектор развития и являющихся «флагманами» различного рода, на которые (не)осознанно ориентируются отстающие от них страны. Именно по этой причине возникает так называемое соотношение или релятивность как основание модернизации общественных структур. Кроме того, реализуется идея относительности некоторых стандартов развитости государства. Исходя из этого, делается вывод о том, что в рамках этого подхода к пониманию сущности модернизации возникает ее связь с глобализацией, заключающаяся в понимании разницы в развитии стран, что вызывает стремление отстающих стран достигнуть развития стран более развитых.

Другим подходом к сущности модернизации является подход «зависимого развития», истоки которого по праву принадлежат школе диффузионизма. Суть этого подхода заключается во взаимодействии между более и менее развитыми обществами, которое приводит к обогащению первых более развитых - за счет перераспределения всевозможных благ и услуг. Поскольку более развитые общества обладают более привлекательными условиями для жизни и развития людей, они притягивают к себе больший объем ресурсов во всех сферах жизнедеятельности. Также выделяется так называемый «догоняющий» подход к сущности модернизации, суть которого 
заключается в стремлении отстающих стран догнать в развитии более развитые (Нехода, 2007).

Проведя даже такой краткий анализ существующих подходов к выявлению сущности модернизации, мы делаем вывод, что одним из оснований необходимости модернизирования общества и его социально-политической структуры является факт определенной формирующейся структуры мирового порядка. Такая структура предстает в виде стран-лидеров (страны так называемого «ядра»), задающих мировое развитие, и стран периферии и полупериферии. Отсюда происходит определенное геополитическое распределение властных, экономических, технологических, социально-демографических и других видов межобщественных отношений (Валлерстайн, 2018). Именно здесь возникает вполне осязаемая философская проблема «Другого», которая реализуется на политическом, государственном и всех других уровнях. Также встает вопрос о национальной безопасности конкретного общества, поскольку «периферия» по причине своей неразвитости может впасть в существенную зависимость некоторого плана (экономического, политического, социального и даже духовного) от более развитых обществ.

Справедливо утверждать, что национально-культурная идентичность является универсальным способом отделения «своих» от «чужих». В качестве исторических причин постановки вопроса о культурно «Другом» мы рассматриваем существующие и протекающие в любом обществе центробежные и центростремительные процессы (Волкова, 2008). Так появляется необходимость отделения «своего» от «варвара», принадлежащего к иной культуре, существа, способного нанести вред «нашей» культуре, образу жизни, культурной идентичности и идентификации. Следует отметить, что на современном этапе социального развития общества, совпадающем в ряде стран с модернизационными процессами, появляется проблема социального, политического и даже культурного «Другого». Появление этой проблемы связывают с исследованием сощиальных и культурных процессов, «в которых Другой становится неустранимым, изначально данным и влияющим на ситуацию началом» (Галимова, 2015: 103).

Т. П. Волкова указывает, что в понятии «культура» главным является вопрос о культурных различиях, которые «не могут быть устранены, размыты, нейтрализованы без ликвидации носителей этой культуры» (Волкова, 2008: 85). Отсюда, по ее мнению, возникают две тенденции. Первая из них связана с необходимостью защиты «своей» культуры. Другая же обусловлена потребностями использования методологии мультикультурализма, предполагающего требование понимания другой культуры, Другого как такового, а также необходимость правового признания равенства иных культур и их носителей. Анализ представленных в работе Волковой проблем мы сводим к 
выводу, что критерий степени цивилизованности общества и культуры состоит в способности принимать представителя иной культуры в качестве равного себе.

Подведем вполне резонный промежуточный итог. Сама идея модернизации в современном освещении предполагает возможности столкновения любых обществ с принципиально иными, чье развитие во всех областях может оказаться существенно выше или ниже, что предполагает необходимость защиты собственных государственных структур, прав на их формирование, способности и возможности самостоятельного развития. Таким образом, необходимость национальной безопасности видится в том, что этот процесс позволяет провести границы между «своей» культурой, государством и обществом и теми же образованиями в значении «Другого». Как результат способность, говоря образно, «фильтровать» тех, кто представляет опасность для «меня» и «моего» общества, а кто может оказаться в отношении «меня» дружественным. Вопрос критериев различия между первыми и вторыми, в конечном счете, приводит к необходимости реализации обеспечения национальной безопасности как формирования безопасного существования «своего» государства и общества.

По мнению Е. А. Бритиковой, самой идеей прогресса так называемый «Западный мир» бросает вызов всем остальным обществам именно по причине стремления к доминированию в общепланетарном масштабе (Бритикова, 2014). Вполне вероятно, что причиной этого является неспособность отстающих обществ (ис)пользовать в полном объеме достижения «западной цивилизации», что влечет зависимость их подавляющего числа от наиболее развитых (Губаев, 2012). Таким образом, те, кто пытается догнать «Западный мир» априори попадает в зависимость от него, поскольку либо они оказываются в зависимости от более сильного соседа, либо вступают в модернизационную гонку, созданную и раскрученную именно Западом. По причине того, что их технологическое развитие в социально-политической жизни является более эффективным, менее развитые общества зависимы от идей усовершенствования собственных социально-политических структур.

Вторым обоснованием необходимости социально-политической модернизации становится философская идея эпохи Просвещения. Согласно ей, модернизация социально-политической структуры общества неразрывно связана с развитием экономики, в которой реализуются трансформации социального организма. Очевидно, что «модернизация» своим содержанием имеет трансформации практической направленности, что означает первоочередную необходимость формирования совокупности материальных носителей, позволяющих достичь определенных поставленных целей. При этом на социальном и политическом уровне появляется необходимость достижения сба- 
лансированности области политики и социальной сферы жизни общества для полноценного существования человеческого ресурса. Как показывает анализ XVIII века, суть модернизации заключалась в стремлении осовременить (с учетом исторической ретроспективы) социальную и политическую сферы общества и государства и довести их развитие до уровня и состояния экономической сферы. Отсюда заключаем, что в XX-XXI вв. содержание модернизационных процессов сведено к формированию обороноспособности страны, ежегодным достижения прогрессирующего уровня техникотехнологического развития и «цифровизации» экономики, что позволило бы реализовать определенный уровень безопасности (Рахманин, 2011; Трубицын, 2010).

Еще одним аспектом необходимости проведения модернизации (правда, теоретической ориентации) становится само создание конкретной идеи развитости определенного общества. Как мы уже отмечали выше, «Западный мир» сформировал образ успешного развитого сообщества. Это предполагает, что все общества, не соответствующие этому уровню, маркируются как «развивающегося» или «традиционные». «Запад» понимается как идеал в части созданной им совокупности основных институтов. В качестве ориентира речь должна вестись о формировании в традиционных обществах институтов современного западного общества. Сюда относим, например, институты частной собственности, гражданского общества, правового государства, разделения властей и т. д. Необходимость проведения модернизации подобного рода не вызывает сомнений, поскольку именно она приводит к появлению определенных ресурсов, которые бы позволили традиционным обществам обрести стабильность.

Как ни парадоксально, но именно в завершении работы раскрывается актуальность необходимости социально-политической модернизации. Тем более, если речь идет о модернизации в рамках российской действительности. Проблема в том, что по определенным причинам российское общество в значительной степени отстает от стран «Западного мира» в области развития как социально-политической, так и экономической сфер. По нашему мнению, в России на достаточном (для современных реалий) уровне реализовано развитие лишь института частной собственности, чего, естественно, недостаточно для проведения социальной и политической модернизации на высоком уровне. Очередной проблемой, с которой сталкиваются модернизационные идеи, является вопрос о проведении преобразований, связанных с демократизацией политико-властной системы, развитием принципа разделения властей и прочих атрибутов, формирующих ядро демократического общества. Необходимость проведения этой модернизации заключена в том, что в результате проведения определенных преобразований, направленных на осовременива- 
ние политических и правовых методов, которые регламентируют управление обществом, (с)формируется стабильная и эффективная модель самого государства, что, естественно, является существенно значимым для функционирования политической системы общества (Дорожкин, 2012).

Политическая система модернизированного общества становится систематизированной, отточенной, в ней реализуется четкое разделение функций, полномочий, в целом - того, что отличает развитое общество от традиционного. Кроме того, политическая модернизация позволяет сформировать определенную систему политико-властных отношений в виде единства гражданского общества, политической партии и государственной власти. При формировании модернизированного варианта такого единства возникает единое общество, в котором на эффективном уровне сообщаются все базовые элементы общественной структуры (Дорогой, 2015). В результате появляется возможность реализовывать политические и властные интенции в общественной структуре социальной реальности, что в свою очередь дополняется возможностью и самое главное - способностью власти «слышать» общество с его потребностями и запросами.

Таким образом, значимость необходимости проведения социальнополитической модернизации состоит в формировании сильного общества. Под последним понимается такое государство, которое по своему уровню развития окажется самостоятельным, т. е. способным принимать определенные политические, социальные, экономические и прочие решения и претворять их в жизнь независимо (Малева, Овчарова, 2009). Сама функция проведения модернизации социальной, политической и прочих сфер общества заключается в создании некоторой базовой части социальной сферы, которая окажется фундаментом для независимого развития государства. Кроме того, социально-политическая модернизация выполняет и функцию формирования национальной безопасности страны, позволяя дифференцировать социальных субъектов и определять, кто является «своим», а кто «чужим».

\section{СПИСОК ЛИТЕРАТУРЫ}

Бритикова, Е. А. (2014) Модернизация и глобализация: перспективы и противоречия // Общество и право. № 1 (47). С. 286-290.

Валлерстайн, И. (2018) Миросистемный анализ: Введение. 2-е изд., испр. М. : URSS. 304 с.

Волкова, Т. П. (2008) Философская концепция Другого в контексте формирования мультикультурного общества // Вестник Мурманского государственного технического университета. Т. 11. № 1. С. 84-88.

Галимова, А. К. (2015) К проблеме «Другого» в философии // Вестник Воронежского государственного университета. Серия: Философия. № 2 (16). C. 102-111. 
Губаев, Б. Д. (2012) Политическая модернизация в России: проблемы и перспективы реализации // Теория и практика общественного развития. № 3 . С. 232-234.

Дорогой, К. Б. (2015) Политическая модернизация как фактор стабилизации общества в современной России // Вестник Санкт-Петербургского университета. Серия 12: Психология. Социология. Педагогика. № 1. С. 161-167.

Дорожкин, Ю. Н. (2012) Актуальные проблемы модернизации политической системы России // Власть. № 10. С. 10-13.

Малева, Т. М., Овчарова, Л. Н. (2009) Социальная модернизация в России: теория, история, вызовы // SPERO. Социальная политика: Экспертиза. Рекомендации. Обзоры. № 10. С. 11-32.

Нехода, Е. В. (2007) Теории модернизации и догоняющего развития: возможности для России // Вестник Томского государственного университета. № 304. С. 167-169.

Рахманин, В. С. (2011) Философские парадигмы модернизации // Вестник Волгоградского государственного университета. Серия 7: Философия. Социология и социальные технологии. № 2 (14). С. 42-48.

Трубицын, Д. В. (2010) Марксизм как ранний аналог концепции модернизации (философский анализ проблемы модернизации незападных стран) // Гуманитарный вектор. № 1. С. 152-162.

Штомпка, П. (1996) Социология социальных изменений. М. : Аспект Пресс. 416 c.

Дата поступления: 18.01.2018 г.

Равочкин Никита Николаевич - кандидат философских наук, доцент кафедры гуманитарно-правовых дисциплин Кемеровского государственного сельскохозяйственного института. Адрес: Россия, 650056, г. Кемерово, ул. Марковцева, д. 5. Эл. адрес: nickravochkin@mail.ru

Ravochkin Nikita Nikolaevich, Candidate of Philosophy, Associate Professor, Department of Humanities and Legal Disciplines, Kemerovo State Agricultural Institute. Postal address: 5, Markovtseva St., 650056 Kemerovo, Russian Federation. E-mail: nickravochkin@mail.ru

\section{Для циитирования:}

Равочкин Н. Н. Необходимость социально-политической модернизации [Электронный ресурс] // Горизонты гуманитарного знания. 2018. № 1. С. 3744. URL: http://journals.mosgu.ru/ggz/article/view/701 (дата обращения: дд.мм. гггг). DOI: 10.17805/ggz.2018.1.3 